\title{
ROLE OF THE JUDGE IN CREATING JUSTICE AS AN INSTRUMENT OF SOCIAL CHANGE
}

\author{
Muh. Yusuf \\ The High Attorney of South Sulawesi Province, Indonesia. \\ E-mail: muhammadyusuf@yahoo.com \\ Ichsan Yasin Limpo \\ Graduate School Hasanuddin University, Indonesia. \\ E-mail: ichsanyasinlimpo@gmail.com \\ Deasy Mauliana \\ National Institute of Public Administration, Makassar, Indonesia. \\ E-mail: deasy.mauliana@yahoo.com \\ Andi Bau Mallarangeng \\ STIH Lamadukelleng, Sengkang,Indonesia. \\ E-mail: andibmallarangeng@yahoo.co.id \\ Makkah Hm \\ Universitas Indonesia Timur, Makassar, Indonesia. \\ E-mail: dosen.makkah@yahoo.co.id
}

\begin{abstract}
The roles of the judges in creating justice has been social phenomenon in society. Public response arises not only because it is so principal but also because the people want and expect that judges at all levels of the courts are qualified and have high integrity and social sensitivity so that it can resolve the problems in the legal field. This paper attempts to unravel the main duties of the judges solving the cases. It concludes in order to meet the demands of justice, the paradigm, mindset and behavior of judges that have tended to weaken and humiliate the position and dignity of the judiciary need to be changed and developed. To realize the existence of the role of judges is determined by the performance, professionalism, idealism and adequate infrastructure to support the efforts of both internal and external approach.
\end{abstract}

\section{Keywords: Judges; Justice; Social Change}

\section{Introduction}

A judge, or other law enforcement agencies often accentuate his belief as the ultimate weapon to give an explanation of what it decides, even though it might actually that he was trying to convince himself to the problem being faced. It seems easy to explain, but it's very difficult to be accepted or understood. Many judges fail to use intuition and beliefs, then sometimes it causes enormous losses for certain parties.
As a professional, the judges generally get enough by arguing that their mistakes are not intentional, but something which is beyond their capacity that could be happened anytime and anywhere. ${ }^{1}$ Considerations had been made and assigned by judges might be wrong, but more than what have been stated above, this problem

\footnotetext{
${ }^{1}$ Achmad Ali, Wiwie Heryani. (2013). Menjelajahi Kajian Empiris Terhadap Hukum. Jakarta : Kencana Prenada Media. pg. 43
} 
appeared mostly as a form of "distortion of communication".

The judge, as one of the most important components of a judicial institution, become hot topic nowadays, as the public attention focused on judicial institutions. Some decisions aroused controversy in the community, there are pros, but some also give strong responses to the behavior of judges who adjudicate the cases. Public response arises not only because the urgency of the role of judges is so central, but also because the people want and expect that judges in all levels of the courts are qualified and have high integrity and social sensitivity so that it can resolve the problems.

Indonesia as a former Dutch colony, has a different law system. The decision is in the hands of judges, according to his belief. $^{2}$ Whatever is put forward by prosecutors, advocates, and the defendant in the trial, the final decision is on the judge hands. It causes that the concentration of power is in the judge. So in our system the judge has a possibility to decide things that is not right.

The attention to the existence of a judge, cannot be separated from their strategic role and their esteemed. The judges are implementing judicial power in

\footnotetext{
${ }^{2}$ Henry P. Panggabean. (2001). Fungsi Mahkamah Agung dalam Praktik Sehari-hari. Jakarta : Penerbit Pustaka Sinar Harapan. pg. 11
}

his hands and also the authority to examine and decide the whole case filed against him. The role and position respectable was eroded increasingly by negative behaviors and now many people do not respect to them.

Indeed, the presence of the trial judge is not meant to be a scary monster with its decisions arbitrary outside juridical considerations and the values of justice, but his presence in order to carry out the duties and obligations provided by the law. The judges even in a position to determine the law and based in the peak of the judiciary, but by no means free from bondage of moral norms so as can only act and behave as they wished. The position of judge is a noble and esteemed position, but glory and honor that will appear when it consequently remains in the role that should be followed, otherwise the honor and glory that will be bleak and disappeared when it leaves and keep away from his role. Based on the above background, the objective of this work is to critically review the role of judge in creating a justice as an instrument of social change.

\section{Analysis and Discussion}

As a judicial formal, judges are judicial officials who are authorized by law to prosecute. Judging, is a series of the judges to receive, examine and decide a criminal case based on the principle of 
independency, fair and impartial in the court according to the law.

Effort of separation the judiciary by the executive power has begun with the Decree of MPR No. X / MPR / 1998 dated 13 November 1998 on the Principles of Development Reform in the Context of National Life Rescue and normalization as the State Law, which calls for the division of power between the powers expressly executive and judicial. Then followed by the issuance of Law No. 35 of 1999 on the Amendment of the Law No.14 of 1970 on Basic Provisions on Judicial Power, which states that: all judicial bodies exist (ie the public courts, religious courts, military courts, administrative courts) organizationally, administrative and functional which was originally located under each department be transferred under the authority of the Supreme Court. ${ }^{3}$

Various attempts have been made to establish the authority of the judges. Begins by separating the judiciary from the executive powers related to administrative and financial affairs. This separation is intended to independence and liberation of the judiciary is ensured without any interference from the executive power. ${ }^{4}$ This effort continued with the legislative

\footnotetext{
${ }^{3}$ Bismar Siregar. (1983). Hukum Acara Pidana. Bandung : Penerbit Bina Cipta. pg. 122-124.

${ }^{4}$ Rusli Muhammad. (2006). Potret Lembaga Pengadilan Indonesia. Jakarta : Penerbit Rajawali. pg 32-33.
}

changes that began with Act No.4 of 2004 . Article 23 states that: "Against a court decision which has permanent legal power, the parties concerned may apply for judicial review to the Supreme Court if there is a case or certain circumstances specified in the law". Although this article gives authority to the Supreme Court to Review (PK), but on the other hand, this article while also limiting the Supreme Court in conducting PK, because PK can only be done in things or circumstances prescribed by law, outside of that PK is not allowed. By itself the Supreme Court did not also freely organize PK though it according to justice needs to be done.

As the consequences of state law and the desire to still want an independent judiciary as an institution, in which the Supreme Court placed as the holder of power (judicial) highest. Furthermore, the reform effort is also made to Act 2 of 1986 on General Courts. This is because there are many provisions that regulate the executive authority in the affairs of the judiciary. Various provisions of the rated limit the independence of the judiciary is no longer relevant and has made changes and improvements through Act 8 of 2004, which was later amended by Act 49 of 2009 on the Second Amendment to Act 21986 of the General Court.

Structuring the judiciary with a 
comprehensive set of regulations has moved a step forward. At least the judiciary has been free and independent. Furthermore, no longer depends financially and administratively to the executive. With the freedom and the independency, the judges is expected to be more confident and firm in carrying out the mandate and carried without worrying influenced and swayed from external interferences. ${ }^{5}$ Regrettably, however, the position of a free and independent institution that was not been used properly. Freedom and independence has been compromised and had gone too far. What have been happened is not the freedom and the responsible independency but rather to the abuse of power and betrayal of responsibility.

The condition of the judiciary is still cause for concern, suggesting that changes in the structure and arrangement and refinement of legislation is not enough to improve the performance and image of the judiciary. It seems that improvement efforts do not stop in the field of structure and legislation but also on human resources. In this case, we are reminded by Lawrence $M$. Friedman doctrine that the legal system consists of three (3) components, namely Structure, Substance and Legal Culture.

\footnotetext{
${ }^{5}$ Benny K. Herman. (1997). Konfigurasi Politik \& Kekuasaan Kehakiman di Indonesia. Jakarta : Penerbit ELSAM. pg. 86
}

Friedman ${ }^{6}$ doctrine are very relevant to gain attention, because this doctrine implies that the three components of the legal system must be met, all three are interrelated and all three should receive balanced attention, because when one overlooked cause malfunction and failure of a legal system in achieving its goals. The displacement of position of the judiciary led to the neglection of development and improvement of human resources quality. ${ }^{7}$ Therefore, to restore the position of the judiciary at the central position is noble and honorable, the structure and changes in legislation that has been done so far should also be followed by the arrangement and cultural development (HRD) through increased roles and responsibilities, including and foremost human resources of the judges.

Furthermore, Judicial Authority law already provides for a judge position is as one of the executors of judicial power for the people seeking justice. Position is actually a media which contents certain rights and obligations. The rights and obligations are role or "rule". Thus, the Supreme Court Justice, including other judges are seeking justice for the people contains rights and obligations, means the authorized. The role is as mentioned above,

\footnotetext{
${ }^{6}$ Lawrence M. Friedman. (1975). The Legal System, A Social Science Perspective. New York : Russell Sage Foundation. pg 58.
} 
among others organize judiciary to enforce the law and justice. ${ }^{7}$ Those roles are the ideal roles.

Meanwhile, the law gave the task to receive, examine and adjudicate and resolve any matter referred to it by the principle of simple, fast and low cost, and judge according to the law with no distinguishing people. The task is another form of the role of the judge, but the role has not given good sense for the judiciary itself and the justice seekers because, if only limited to the role of stopping means judges have not done an actual role or actual role. Therefore, judges must also realize that role. The actual role of these are related to the real behavior of the judges, the judges on the one hand to apply the legislation and on the other hand do the discretion in certain circumstances.

Judges have substantial power to the parties with respect to any problems or conflicts that were introduced to the judge or judges. And also means that the judges in performing their duties fully assume great responsibility and must be aware of his responsibility, because the judge's decision can have disastrous consequences very much on the lives of the justiable or others affected by the reach of the decision. The decision unjust judge can even lead to emotional and physical suffering that can be burned into the mind throughout his life.

\footnotetext{
${ }^{7}$ Rusli Muhammad. Op. Cit.pg 82.
}

The judges' verdict is likely to use the normative juridical considerations, indicate judges always use the size of the legislation as a knife in solving problems. Logic is logic deductive thinking, which puts the rules or code of laws that are common in concrete cases. When things are mentioned in the law has appeared in court, then that is taken into consideration the judge, without having to look at other things. The judge thought cannot be separated from his position as a professional whose views always see and understand the law as regulations (rules). ${ }^{8}$

Juridical responsibility of the judges demanded that always harmonize every step of life with the law. When confronting and resolving cases completed with the logic and legal doctrine, without weighing and it occurred to aspects outside the law. Similarly, when it will formulate and make a decision, at its sole discretion juridical considerations. The process and the formulation of decisions made by any judge beside based on the normative rules, also based on the spirit of the oath and the promise contained in the head of every decision. Oath and this promise is the spiritual foundation for each judge who encouraged him to always remember the responsibility to the law, to ourselves and to

\footnotetext{
${ }^{8}$ Soerjono Soekanto. (1983). Faktor-faktor yang Mempengaruhi Penegakan Hukum. Jakarta : Penerbit Rajawali. pg. 91
} 
the people, and God Almighty. Therefore, it is deemed important for the judge not only as a skilled attendant increase technical competence in the field of law (justice) but also private must reflect the prestige that a judge is the representative of god in resolving any dispute that it faces.

The judges who work and work in accordance with the duties and functions mentioned above, the judges of this kind will be able to give a decision containing justice based on God. ${ }^{9}$ And perhaps judge this kind is precisely what is referred to as Omo iudex namely personal expert and skilled in the law, wise, honest and upholds justice is not just law, but also as a translator and as human decency thinkreasoned and considered by justice. Similarly, the judge will not be idle and silent, the judge will keep working and try to achieve justice despite the case at hand there is no law. When you find such cases the judge seeks to explore and discover the law by relying on the values that live in the community.

Not easy to fulfill these requirements, can only be met with an open mind and judge his eyes. Judges were always involving copyright (logos), intention (ethos) and taste (pathos) in life and living, honest and always pray to God. The role of

\footnotetext{
${ }^{9}$ Anwarul Yaqin. (1998). Law, and Society in Malaysia, International Law Book Servie. Malaysia : Kuala Lumpur. pg. 19.
}

judges is so, is not wrong if categorized as a scientific thinking. This means that even if judges are in the professional world but what it does not solely within the framework of professionalism but also in terms of scientific, as where seen in the decision making, where the judge does not merely work to create and establish the decision to view and apply the rules abstract law but judges always look at the problems faced in a wider context. The rule of law that it faces are not seen as an abstract and truthful as it is written, but it sees as the content and the process of formulation may change from time to time in accordance with the conditions and demands of public justice at the time.

In order to meet the demands of justice, the paradigm, mindset and behavior of judges that have tended to weaken and humiliate the position and dignity of the judiciary need to be changed and developed. This means that the role of judges in itself should be developed to a more responsive and reformers, judges no longer simply an agent of translators and apply the rule of law into the events of concrete or deliver a verdict in many cases, but its role is directed towards the return of a positive image of the judiciary as one of the central institutions. To that end, the judge makes the judiciary as an institution independent primary and decisive, as the central institution not as a 
marginal institution dependent and controlled by the influence of power, politics and economics are misguided.

Because the judge's ruling should embody "For the sake of justice based on God", the sentence is always the beginning of a verdict is the relationship between subjective and objective judge, the facts and the legal rules that were introduced to a judge in concrete cases are being examined in court. Freedom took a decision that is too big (ignoring the three elements) brought the situation to legal uncertainty, creating space subjectivity of judges, and raises questions legitimates. The combined balance of the relationship between subjective and objective then it can be shown that the quality of the court. Objective element can be obtained from the formulation of the offense in the legislation, while the subjective element obtained from judges who are experts, meet the requirements of the appointment as a judge, and has extensive community experience, good intelligence, and dedication to the positions.

\section{Conclusion}

The judges as the most important organ of the judiciary under the Act of 1945 is authorized to run the judicial power, namely the power to organize judicial administration to uphold law and justice, with the main task to receive, examine and adjudicate and resolve each case brought before it. The judge responsible for the judicial process and the decision on all matters brought before it by using logic and doctrine of law and principles of justice. Judges in law enforcement is obliged to justice despite facing no case law to explore, and understand the values that live in the community.

The judge is a buffer of law, justice and truth dignified, honest and transparent and not as a supplier interests of power, authorities and entrepreneurs. Each judge devoted to the rule of law in order to restore law and public confidence crisis. Judges always make legal institutions as the primary independent and decisive, as the central institution not as a marginal institution dependent and controlled by the influence of power, politics and economics are misguided. Future judges must be willing and actively eradicate and prevent mob justice and make sterile Judiciary of judicial mafia. To realize the existence of the role of judges is determined by the performance, professionalism, idealism and adequate infrastructure to support the efforts of both internal and external.

\section{Reference}

Achmad Ali, Wiwie Heryani. 2015. Sosiologi Hukum, Kajian empiris Terhadap Pengadilan. Jakarta, Kencana Prenada Media. 
Achmad Ali, Wiwie Heryani, 2013, Menjelajahi Kajian Empiris Terhadap Hukum, Jakarta, Kencana Prenada Media.

Achmad Ali, 2012, Resep Hukum: Sebuah Bunga Rampai, Jakarta, Kencana Media.

Anwarul Yaqin, 1998, Law, and Society in Malaysia, International Law Book Servies, Kuala Lumpur, Malaiysia.

Benny K. Herman, 1997, Konfigurasi Politik \& Kekuasaan Kehakiman di Indonesia, Penerbit ELSAM, Jakarta.

Bismar Siregar, 1983, Hukum Acara Pidana, Penerbit Bina Cipta, Bandung.

Henry P. Panggabean, 2001, Fungsi Mahkamah Agung dalam Praktik Sehari-hari, Penerbit Pustaka Sinar Harapan, Jakarta Lawrence M. Friedman, 1975The Legal System, A Social Science Perspective, Russell Sage Foundation. New York.

Rusli Muhammad, 2006, Potret Lembaga Pengadilan Indonesia, Penerbit Rajawali, Jakarta. Soerjono Soekanto, 1983, Faktor-faktor yang Mempengaruhi Penegakan Hukum, Penerbit Rajawali, Jakarta. 